\section{PERAN INTERNATIONAL COMMITTEE OF THE RED CROSS DALAM PERLINDUNGAN KORBAN PERANG MENURUT KONVENSI JENEWA $1949^{1}$ Oleh : Yehezkiel Rober Antouw ${ }^{2}$}

\begin{abstract}
ABSTRAK
Tujuan dilakukannya penelitian yaitu untuk mengetahui bagaimana peran International Committee of the Red Cross dalam perlindungan korban perang menurut Konvensi Jenewa 1949 dan bagaimana pengaturan Konvensi Jenewa (Hukum Humaniter) dan Hak Asasi Manusia dalam hal perlindungan korban perang, di mana dengan metode penelitian hukum normatif disimpulkan: 1 . Peran ICRC untuk melindungi para korban perang, diklasifikasikan pada dua kondisi, yaitu Sengketa Bersenjata Internasional (Perang Antar Negara) dan Sengketa Bersenjata NonInternasional (Perang Dalam Negeri). Adapun peranan International Committee of the Red Cross termuat juga dalam pasal 5 Statuta Gerakan Palang Merah dan Bulan Sabit Merah; 2. Hukum Humaniter dan Hukum HAM memang merupakan dua hal yang memiliki perbedaan cukup jelas, namun Hukum Humaniter dan Hukum HAM saling melengkapi. Dimana keduanya berusaha untuk melindungi kehidupan, kesehatan dan martabat individu walaupun dilaksanakan dalam situasi dan cara yang berbeda. Hukum Humaniter berlaku pada situasi konflik bersenjata, sedangkan Hukum HAM melindungi individu setiap saat, baik pada masa perang maupun dalam masa damai. Hukum Humaniter ditujukan untuk melindungi orang-orang yang atau tidak lagi terlibat dalam permusuhan, sedangkan Hukum HAM berlaku untuk siapa saja.
\end{abstract}

Kata kunci: korban perang; red cross;

\section{PENDAHULUAN}

\section{A. Latar belakang}

Dengan melihat pola perkembangan konflik ala abad XX yang kurang memperhatikan aspek keberadaan perang dan mengabaikan keselamatan pihak non-combatant maupun korban dari pihak militer, maka Palang Merah Internasional (International Committee of the

\footnotetext{
${ }^{1}$ Artikel Skripsi. Dosen Pembimbing: Dr. Corneles Massie, $\mathrm{SH}, \mathrm{MH}$; Dr. Natalia Lengkong, SH,MH

2 Mahasiswa pada Fakultas Hukum Unsrat, NIM. 16071101139
}

Red Cross) berupaya agar hak-hak noncombatant dan tawanan perang dihargai dan dihormati dengan upaya penguatan Hukum humaniter internasional (IHL/International Humanitarian Law). Hukum humaniter internasional merupakan cabang dari hukum internasional yang berlaku dalam situasi perang dan konflik bersenjata. Hukum ini diperlukan untuk meringankan penderitaan akibat kondisi perang dan konflik bersenjata dengan cara melindungi korban yang tidak bisa mempertahankan diri dan dengan mengatur sarana dan metode peperangan.

\section{B. Perumusan Masalah}

1. Bagaimana peran International Committee of the Red Cross dalam perlindungan korban perang menurut Konvensi Jenewa 1949?

2. Bagaimana pengaturan Konvensi Jenewa (Hukum Humaniter) dan Hak Asasi Manusia dalam hal perlindungan korban perang?

\section{Metode Penelitian}

Penelitian ini menggunakan pendekatan hukum normative.

\section{PEMBAHASAN}

A. Peran International Committee of the Red Cross Dalam Perlindungan Korban Perang Menurut Konvensi Jenewa 1949

Hampir setiap hari ada berita mengenai pemboman desa-desa, serangan yang diarahkan kepada sasaran sipil, perlakuan yang tidak baik terhadap tawanan perang, penyiksaan, pemerkosaan, eksekusi di luar proses hukum, masyarakat sipil yang kelaparan dibawah pendudukan musuh, dsb. Hal-hal seperti ini yang nantinya membutuhkan peranan penting dari ICRC.

Kegiatan ICRC yang bersifat preventif ${ }^{3}$ dirancang untuk membatasi efek buruk dari konflik dan meminimalkan efek-efek semacam itu. Oleh karena itu, ICRC berusaha untuk menyebarluaskan seluruh rangkaian prinsip kemanusiaan dalam rangka mencegah atau sekurang-kurangnya membatasi ekses-ekses terburuk dari peperangan. Ada sejumlah

\footnotetext{
3 Preventif. Bersifat mencegah terjadinya sesuatu.
} 
tindakan preventif yang dilakukan oleh ICRC, yaitu:

1. Mencegah melalui komunikasi, dalam program preventifnya, target ICRC secara khusus ialah orang-orang dan kelompokkelompok yang berada dalam posisi untuk menentukan nasib para korban konflik bersenjata atau yang dapat menghalangi atau memfasilitasi kegiatan ICRC. Kelompok-kelompok tersebut antara lain angkatan bersenjata, kepolisian, pasukan keamanan dan pihakpihak bersenjata lainnya, para pengambil keputusan, dan para tokoh masyarakat di tingkat lokal maupun internasional, para remaja, mahasiswa dan para pengajar. Strategi di balik kegiatan-kegiatan tersebut terdiri dari tiga tingkatan:

- Membangun kesadaran

- Mempromosikan Hukum Humaniter Internasional (HHI) melalui kegiatan pengajaran dan pelatihan

- Mengintegrasikan HHI ke dalam kurikulum resmi di bidang hukum, pendidikan, dan operasi.

Tujuan akhir dari program-program preventif adalah mempengaruhi sikap dan perilaku orang-orang dalam rangka meningkatkan perlindungan terhadap orang-orang sipil dan korban-korban lain pada masa konflik bersenjata, memfasilitasi akses terhadap korban, dan meningkatkan keamanan bagi kegiatan kemanusiaan.

2. Menghormati dan menjamin penghormatan, Negara berkewajiban menjamin bahwa angkatan bersenjatanya menguasai $\mathrm{HHI}$ dan prinsip-prinsip kemanusiaan universal. Untuk itu, ICRC mempromosikan pengintegrasian $\mathrm{HHI}$ dan prinsip-prinsip kemanusiaan ini ke dalam doktrin, pendidikan, pelatihan militer serta membantu Negara-negara melaksanakan proses tersebut.

ICRC juga berupaya agar pihak kepolisian dan keamanan menerima pelatihan $\mathrm{HHI}$, hukum, HAM, dan prinsip-prinsip kemanusiaan universal. Kepada kelompok senjata yang belum pernah mendapatkan pelatihan, ICRC berusaha menjalin kontak dengan semua pihak yang terlibat dalam konflik untuk memperkenalkan kegiatan dan cara kerja ICRC, PM dan BSM, supaya akses untuk membantu korban menjadi lebih mudah dan keamanan pekerja kemanusiaan lebih terjamin.

3. Mengubah keadaan, guna menghindari tumpang tindih kegiatan kemanusiaan yang dilakukan oleh berbagai kalangan, ICRC berupaya agar para pengambil keputusan, tokoh masyarakat, anggota LSM, wartawan, dan orang-orang yang berpengaruh lainnya mengenal kegiatankegiatan ICRC sehingga akan memperoleh dukungan dalam menjamin implementasi $\mathrm{HHI}$. Untuk itulah, ICRC melakukan diplomasi kemanusiaan yang antara lain berupaya menjalin serta memelihara jaringan kontak dengan berbagai pelaku kemanusiaan dan mengkoordinasi kegiatan dengan pelakupelaku lain di lapangan.

4. Mengamankan masa depan, untuk menjangkau calon pembuat keputusan dan tokoh masyarakat, ICRC memprioritaskan dunia akademi, terutama Fakultas Hukum, IImu Politik, dan Jurnalistik sebagai sasaran diseminasinya untuk mendorong dimasukkannya HHI kedalam berbagai program pelajaran yang diselenggarakan. ${ }^{4}$

Adapun peranan ICRC (Pasal 5 Statuta Gerakan Palang Merah dan Bulan Sabit Merah) terutama adalah:

a) Mempertahankan dan menyebarkan Prinsip-Prinsip Dasar Gerakan.

b) Mengakui Perhimpunan Nasional yang baru dibentuk atau yang dibentuk kembali, yang memenuhi syarat-syarat pengakuan yang ditetapkan dalam pasal 4 (Statuta), dan memberitahukan Perhimpunan-perhimpunan Nasional lainnya mengenai pengakuan tersebut;

c) Menjalankan tugas yang dibebankan kepadanya berdasarkan Konvensikonvensi Jenewa, bekerja untuk penerapan hukum humaniter internasional yang berlaku dalam sengketa bersenjata secara tepat dan

\footnotetext{
${ }^{4}$ Ambarwati, dkk, Op.Cit. hlm. 147.
} 
mengambil tanggung jawab atas pengaduan apa pun yang didasarkan pada dugaan pelanggaran hukum tersebut;

d) Sebagai lembaga netral yang memiliki tugas kemanusiaan yang dijalankan terutama pada waktu sengketa bersenjata internasional atau lainnya atau kerusuhan internal, pada segala waktu berusaha untuk menjamin perlindungan dan bantuan kepada para korban sipil dan militer dari peristiwa tersebut dan akibat-akibat langsungnya.

e) Menjamin operasi The Central Tracing Agency (Badan Pencari Pusat) sebagaimana ditentukan dalam Konvensi-konvensi Jenewa;

f) Dalam antisipasi sengketa-sengketa bersenjata, memberikan sumbangan untuk pelatihan personil kesehatan dan penyiapan perlengkapan kesehatan, bekerja sama dengan Perhimpunanperhimpunan Nasional, dinas kesehatan militer dan sipil dan para penguasa yang berwenang lainnya;

g) Bertugas memberikan pemahaman dan penyebaran pengetahuan dalam sengketa bersenjata untuk mempersiapkan perkembangannya;

h) Melaksanakan mandate yang dipercayakan kepadanya oleh Konferensi Internasional Palang Merah dan Bulan Sabit Merah (The Internasional Conference). ${ }^{5}$

Prinsip-prinsip Dasar Gerakan Palang Merah dan Bulan Sabit Merah yang Wajib Dipatuhi Oleh ICRC.

1. Kemanusiaan

Gerakan yang lahir dari keinginan untuk memberikan bantuan tanpa diskriminasi kepada korban luka di medan pertempuran, berusaha dengan kemampuan internasional maupun nasionalnya untuk mencegah dan meringankan penderitaan manusia di mana saja. Tujuan gerakan ini adalah untuk melindungi kehidupan dan kesehatan serta memastikan penghormatan terhadap umat manusia. Gerakan memajukan saling pengertian, persahabatan, kerja sama, dan perdamaian abadi di antara semua bangsa.

2. Ketidak berpihakan (dalam membantu korban)

Gerakan ini tidak membeda-bedakan kebangsaan, ras, agama, status social, atau pandangan politik korban. Gerakan membantu korban hanya atas dasar kebutuhan mereka. Bantuannya diprioritaskan bagi kasus penderitaan yang paling mendesak.

3. Kenetralan (dalam menghadapi konflik/ kontroversi)

Agar tetap dipercaya oleh semua pihak, gerakan tidak akan berpihak dalam konflik yang terjadi dan tidak akan terlibat dalam pertentangan politik, ras, keagamaan, ataupun ideologis.

4. Kemandirian

Gerakan ini mandiri. Setiap perhimpunan nasional, sekalipun merupakan pendukung pemerintah masing-masing di bidang kemanusiaan dan tunduk pada hukum nasional pada negaranya, hams mempertahankan otonominya supaya dapat bertindak sesuai dengan prinsipprinsip gerakan.

5. Kesukarelaan

Gerakan ini merupakan sebuah gerakan yang memberikan bantuan atas dasar kesukarelaan, tidak didorong dengan cara apapun oleh keinginan untuk memperoleh keuntungan tertentu.

6. Kesatuan

Hanya boleh ada satu Perhimpunan Palang Merah dan Bulan Sabit Merah di suatu Negara; perhimpunan itu harus terbuka bagi semua orang; perhimpunan harus melaksanakan tugas kemanusiaan di seluruh wilayah negaranya.

7. Kesemestaan

Gerakan Palang Merah dan Bulan Sabit Merah Internasional, di mana semua perhimpunan nasional mempunyai status yang setara dan tanggung jawab, serta kewajiban yang sama dalam membantu satu sama lain, ada di seluruh dunia. ${ }^{6}$

ICRC dapat mengambil inisiatif kemanusiaan yang muncul di dalam perannya sebagai lembaga yang secara khusus bersifat netral dan

\footnotetext{
${ }^{5}$ Ambarwaty, dkk., Op Cit, hlm. 145.
}

\footnotetext{
${ }^{6} \mathrm{lbid}, \mathrm{hlm} .146-147$
} 
mandiri dan sebagai penengah, dan dapat mempertimbangkan persoalan yang memerlukan pengawasan oleh suatu lembaga. ${ }^{7}$

Sejak Konvensi Jenewa I Tahun 1864, ICRC berupaya meningkatkan perlindungan bagi korban perang dengan cara mendorong Negara-negara untuk menyusun dan mengadopsi standar-standar hukum yang baru. Para ahli hukum menyelenggarakan dan berpartisipasi dalam rapat-rapat dan konferensi-konferensi mengenai permasalahan kemanusiaan. Melalui pelayanan konsultasi HHI-nya, lembaga ini juga mendorong Negaranegara untuk mengadopsi peraturan-peraturan perundang-undangan yang memberlakukan $\mathrm{HHI}$ di tingkat nasional. Selain itu, memberikan bantuan teknis kepada Negara-negara menyangkut undang-undang untuk menuntut penjahat perang dan melindungi lambang PM dan BSM.

Bilamana melihat pelanggaran aturan perang, ICRC akan mengadakan pendekatan rahasia kepada pihak yang bertanggung jawab atas peristiwa tersebut. Jika pelanggarannya serius, berulang dan dipastikan akan terjadi lagi, sementara pendekatan rahasia itu gagal, ICRC berhak menyatakan pendirian di depan umum dengan mengecam kegagalan untuk menghormati HHI. ${ }^{8}$

Blokade yang dilakukan Israel, juga menyulitkan ICRC untuk melaksanakan program rekonstruksi Gaza meski sudah tersedia dana sebesar 4,5 juta dollar AS. Menurut ICRC, rakyat Gaza masih kesulitan mendapatkan layanan kesehatan, kekurangan persediaan air bersih tidak tersedianya sistem sanitasi dan rumah yang layak untuk tempat tinggal. Ratusan pasien meninggal dan ratusan pasien lainnya dalam kondisi kritis karena ketiadaan obat dan terbatasnya peralatan rumah sakit di Gaza, sementara Israel tidak mengizinkan para pasien itu keluar Gaza untuk berobat.

ICRC mendesak rezim Zionis agar memberi ijin masuk bagi truk-truk yang mengangkut berbagai peralatan, pipa-pipa air, bahan bangunan dan kebutuhan dasar lainnya yang diperlukan untuk proses rekonstruksi. Tap! desakan itu tidak digubris Israel.

\footnotetext{
7 Rover. C, Op.Cit. hlm. 126.

${ }^{8}$ Ambanvati, Denny Ramhdany, Rina Rusman, Op.Cit. hlm. 148.
}

Dalam laporannya, ICRC menyatakan tingkat kemiskinan warga Gaza sudah mencapai level yang membahayakan, yang berdampak pada makin bertambahnya jumlah anak-anak Gaza yang menderita gizi buruk. Sampai saat ini, ribuan orang di Gaza tidak punya rumah karena rumah mereka hancur akibat agresi brutal Israel bulan Januari lalu. Lebih dari 70 persen dari 1,5 juta warga Gaza hidup di bawah garis kemiskinan. Satu dari sembilan keluarga di Gaza pendapatannya kurang dari 250 dollar per bulan.

Cara lain yang digunakan ICRC yaitu mengingatkan dunia internasional untuk lebih memperkuat tekanannya pada Israel agar segera mengakhiri blokade di Jalur Gaza yang sudah berlangsung selama dua tahun dan membuat warga Gaza menderita. Organisasi Palang Merah Internasional itu menegaskan, bantuan kemanusiaan saja tidak cukup untuk meringankan penderitaan warga Gaza karena yang terpenting adalah penyelesaian politik yang tegas dari pihak-pihak yang terkait terhadap kebijakan kejam Israel untuk memulihkan kembali kehidupan warga Gaza. ${ }^{9}$

Dalam hal seperti di atas, ICRC tidak bertugas untuk melakukan penyelidikan atau penuntutan atas pelanggaran HHI. Setiap Negara peserta Konvensi-konvensi Jenewa wajib memasukkan ke dalam pelanggar $\mathrm{HHI}$ termasuk mengenai penuntutan dan ekstradisi atas penjahat perang. Pelaku pelanggaran dapat dihadapkan ke pengadilan nasional negaranya atau ke mahkamah internasional. Statuta Roma 1998 tentang Mahkamah Pidana Internasional (Internasional Criminal Court/ICC) mulai berlaku tahun 2002, melahirkan sebuah badan yang diakui secara internasional untuk mengadili pelaku kejahatan perang yang lolos dan sistem pengadilan nasionalnya. Aturan ICC mengecualikan staf ICRC dari kewajiban memberikan pembuktian karena jika dapat dipanggil sebagai saksi dalam prosedur pengadilan ini, kenetralan ICRC akan terancam sehingga beresiko terhadap aksesnya yang tidak memihak ke korban konflik. ${ }^{10}$

\footnotetext{
${ }^{9}$ Lihat http://wvyw.eramuslim.com/berita/palestina/gaza kritis ICRC desak dunia internasional tekan israel.htm, diakses tanggal 10 Oktober 2019.

10 Ambarwati, Denny Ramhdany, Rina Rusman, Op.Cit. hlm. 148.
} 
ICRC juga aktif mengupayakan agar senjata yang digunakan maupun senjata yang masih dalam pengembangan sesuai dengan ketentuan $\mathrm{HHI}$, yang berpuncak dengan diadopsinya Konvensi Ottawa tahun 1977 tentang Pelarangan atas Penggunaan, Penimbunan, Pembuatan, dan Pemidanaan Ranjau Darat Anti Personil dan tentang Penghancurannya.

Sebelum masuk pada hal yang lebih spesifik mengenai hak inisiatif dari ICRC, perlu pun melihat tindakan apa yang akan dilakukan ICRC pada masa perang, perang saudara, kekerasan atau ketegangan internal, secara esensial melindungi dan membantu para korban sipil dan militer. Terdapat tiga segi pada peranan ini.

(1) ICRC pertama-tama membantu memperbaiki status para korban perang melalui hukum, karena ICRC merupakan penyusun Konvensi Jenewa yang menghimpun peraturan-peraturan yang menentukan bagaimana seharusnya para pihak pesengketa memperlakukan musuh yang jatuh ke dalam kekuasaannya.

- Penganjur (penyelenggara) Konvensi-konvensi Jenewa

ICRC bekerja untuk pengembangan dan penerapan hukum humaniter internasional dan untuk pemahaman dan penyebarannya ICRC menjalankan kewajiban yang dibebankan kepadanya berdasarkan Konvensi Jenewa dan Protokol Tambahannya, berusaha keras untuk menjamin bahwa yang terakhir ini diterapkan dan bila perlu tetap memperluas lingkungannya.

(2) Tetapi harus ada penengah di antara Negara-negara, yang memiliki kewajiban tertentu; dan korban perang, yang memiliki hak-hak tertentu. Dan inilah ICRC melangkah dalam aksinya.

- Penengah netral

Pada masa perang, perang saudara atau kekeasan atau ketegangan internal, ICRC bertindak sebagai penengah netral di antara para pihak pesengketa atau permusuhan lainnya, dan berupaya untuk menjamin bahwa orang-orang sipil atau korban militer menerima perlindungan dan bantuan. Untuk melakukan hal tersebut, ICRC mengambil inisiatif kemanusiaan yang sesuai dengan peranannya sebagai lembaga yang secara spesifik netral dan mandiri.

(3) Lagi pula, ICRC memiliki peranan khusus untuk dimainkan di dalam Gerakan, yaitu:

- Pengawal prinsip-prinsip

fundamental

ICRC meyakinkan bahwa prinsipprinsip dasar dijunjung tinggi dalam Gerakan. ICRC juga memutuskan terhadap pengakuan Perhimpunan Nasional, yang kemudian diterima untuk keanggotaan Federasi Palang Merah dan Bulan Sabit Merah dan secara resmi menjadi bagian dari Gerakan Palang Merah dan Bulan Sabit Merah. Putusannya didasarkan pada apakah Perhimpunan Nasional telah memenuhi syarat-syarat yang ditetapkan oleh Konferensi Internasional Palang Merah dan Bulan Sabit Merah. ${ }^{11}$

Lebih spesifik, ICRC memiliki hak inisiatif yang diakui untuk setiap keadaan sengketa di tempatnya melaksanakan tindakan penyelamatan.

1. Dalam Sengketa Bersenjata (Perang)

a. Sengketa Bersenjata Internasional (Perang Antar Negara)

Sengketa bersenjata internasional ${ }^{12}$ dinyatakan dalam ketentuan yang bersamaan dari pasal 2 Konvensi-konvensi Jenewa 1949 sebagai sengketa bersenjata yang melibatkan dua Negara atau lebih, baik sebagai perang yang diumumkan maupun apabila pernyataan perang tersebut tidak diakui oleh salah satu dari mereka. Penggunaan istilah sengketa bersenjata, dalam ketentuan tersebut, berguna untuk mengurangi kemungkinan argumentasi bagi Negara yang berkeinginan menolak pemberlakuan $\mathrm{HHI}$ dengan alasan tindakan yang dilakukannya belum termasuk dalam

11 Rover, C. TO SERVE \& TO PROTECT Acuan Universal Penegakan HAM Internasional Committee of the Red Cross. Jakarta: RajaGrafindo Persada, 1998, hlm. 122.

12 Menurut Draper, yang dimaksud konflik bersenjata yang bersifat intersional adalah konflik dimana berhadapan dua angkatan bersenjata dari Negara yang berbeda. Lihat Permanasari Arlina, dkk, Pengantar Hukum Humaniter, Jakarta: Comite International Geneve, 1999, hlm. 139. 
tindakan yang dilakukannya belum termasuk dalam tindakan perang. Sebab, rumusan dalam pasal 2 Konvensi tersebut menunjukkan, setiap perbedaan yang muncul antara dua Negara dan menyebabkan intervensi ${ }^{13}$ angkatan bersenjata adalah sengketa bersenjata, sekalipun salah satu pihak tidak mengakui keberadaan perang. ${ }^{14}$

Dalam hal sengketa bersenjata internasional (perang antar Negara), ICRC memiliki hak inisiatif berdasarkan traktat ICRC ditegaskan dalam pasal 9 Konvensi Pertama, Kedua, Ketiga dan dalam pasal 10 Konvensi Keempat:

"Ketentuan Konvensi ini tidak merupakan halangan bagi kegiatan-kegiatan kemanusiaan Komite Internasional Palang Merah atau organisasi kemanusiaan yang tidak memihak lainnya yang dengan persetujuan para pihak pesengketa dapat melaksanakan perlindungan atas orang-orang yang luka dan sakit, personil kesehatan dan rohaniawan (Konvensi Pertama), orang yang luka, sakit dan korban karam (Konvensi Kedua), tawanan perang (Konvensi Ketiga,) orang-orang sipil (Konvensi Keempat) dan untuk bantuan mereka".

Pasal 81 Protokol Tambahan I memperkuat hak inisiatif ini sebagai berikut:

"Para pihak pesengketa akan memberikan kepada Komite Internasional Palang Merah semua fasilitas yang ada di dalam kekuasaan mereka sehingga memungkinkannya melaksanakan fungsi kemanusiaan yang ditujukan kepadanya dan bantuan kepada para korban sengketa; Komite Internasional Palang Merah juga dapat melaksanakan kegiatan-kegiatan kemanusiaan lainnya untuk kepentingan para korban, berdasarkan persetujuan para pihak pesengketa bersangkutan".

Dalam kasus khusus tawanan perang dan interniran sipil ICRC diberikan hak khusus, yaitu hak untuk bertindak yang dinyatakan dalam pasal 126 Konvensi Jenewa Ketiga, dan sama dengan pasal 143 Konvensi Jenewa Keempat yang memperhatikan orang-orang sipil:

"Para wakil atau utusan Negara Pelindung akan memperoleh izin untuk menandatangani semua tempat tawanan

\footnotetext{
13 Intervensi. Ikut campur urusan dari pihak ketiga. Lihat Terminologi Hukum.

${ }^{14}$ Ambarwati, Denny Ramhdany, Rina Rusman, Loc. Cit. hlm. 56.
}

perang berada, terutama tempat-tempat penahanan, penjara dan tempat kerja, dan akan memperoleh akses ke semua bangunan yang ditempati oleh para tawanan ... Para utusan Komite Internasional Palang Merah akan menikmati hak prerogatif yang sama".

Dalam hal ini, ICRC memiliki mandat yang jelas: hak mengunjungi para tawanan dan tahanan sipil. Dengan kata lain, Negara-negara tak dapat melarang ICRC bertindak atas nama orang tersebut. ${ }^{15}$

b. Sengketa Bersenjata Non-internasional (Perang Dalam Negeri)

Di bawah judul "Sengketa bersenjata non-internasional" perlu dibahas dua hal:

- Setiap keadaan pecahnya permusuhan nyata dan tak dapat diragukan antara angkatan bersenjata dan angkatan bersenjata pembangkang atau kelompok bersenjata terorganisir lainnya di dalam wilayah suatu Negara.

Dalam keadaan terjadinya sengketa bersenjata non-internasional jenis ini di wilayah salah satu negara pihak pada keempat Konvensi Jenewa 1949, pihakpihak pada sengketa tersebut terikat untuk menerapkan ketentuan pasal 3 yang bersamaan pada konvensi-konvensi tersebut. ${ }^{16}$

Pasal 3 Konvensi-konvensi Jenewa 1949 relevan dengan penahanan serta menentukan aturan-aturan $\mathrm{HHI}$ dan kewajiban para pihak yang berkonflik untuk melindungi korban perang dalam perang yang tidak bersifat internasional. Namun pasal tersebut tidak memberikan kriteria atau definisi sengketa bersenjata noninternasional. ${ }^{17}$

Kasus kedua yang memerlukan pertimbangan dibawah judul sengketa bersenjata non-internasional adalah

- Setiap keadaan angkatan bersenjata atau kelompok-kelompok bersenjata lainnya di bawah kepemimpinan seorang komandan yang bertanggung jawab dan melaksanakan pengawasan atau sebagian wilayah

\footnotetext{
$15 \mathrm{Ibid}, \mathrm{hlm} .129$

$16 \mathrm{lbid}, \mathrm{hlm} 293$.

17 Ambanvati, Denny Ramhdany, Rina Rusman. Hukum Humaniter Internasional dalam Studi Hubungan Internasional. Jakarta: Rajawali Pers, 2009, hlm. 59.
} 
sehingga memungkinkan mereka melakukan operasi militer secara berkelanjutan dan terus-menerus dan melaksanakan Protokol (Protokol II).

Dalam kasus terakhir tersebut, dan dalam hal tidak adanya pengakuan mengenai keadaan darurat perang yang melibatkan penerapan seluruh hukum perang, ketentuan pasal 3 yang bersamaan tetap berlaku. Sebagai tambahan, aturan Protokol Tambahan pada Konvensikonvensi Jenewa 1949, dan yang berkaitan dengan Perlindungan Korban Sengketa Bersenjata non-internasional (Protokol II1977) harus dipatuhi. ${ }^{18}$

Kriteria tentang sengketa bersenjata noninternasional dimuat dalam Protokol Tambahan 11/1977 Tentang Perlindungan Korban Sengketa Bersenjata Noninternasional. Disebutkan, sengketa bersenjata noninternasional yang dimaksud dalam Protokol Tambahan 11/1977 adalah sengketa bersenjata yang terjadi dalam wilayah suatu Negara antara pasukan bersenjata Negara tersebut dengan pasukan bersenjata pemberontak atau dengan kelompok bersenjata terorganisasi lainnya yang terorganisasi di bawah komando yang bertanggung jawab, melaksanakan kendali sedemikian rupa atas sebagian dari wilayahnya sehingga memungkinkan kelompok tersebut melakukan operasi militer yang berkelanjutan dan berkesatuan serta menerapkan aturanaturan HHI yang termuat dalam Protokol Tambahan 11/1977. ${ }^{19}$

Adapun kriteria yang dimaksudkan sebagai pasukan pemberontak yaitu:

1. Merupakan kelompok bersenjata terorganisasi;

2. Berada di bawah komando yang bertanggung jawab;

3. Melaksanakan kendali sedemikian rupa atas sebagian dari wilayah;

4. Mampu melakukan operasi militer yang berkelanjutan dan berkesatuan;

5. Mampu menerapkan aturan-aturan $\mathrm{HHI}$ yang termuat dalam Protokol Tambahan II/1977. ${ }^{20}$

\footnotetext{
${ }^{18}$ Rover. C, Op. Cit. hlm. 294.

19 Ambarwati, Denny Ramhdany, Rina Rusman, Op. Cit. hlm. 59.

${ }^{20}$ Ambarwati, Denny Ramhdany, Rina Rusman, Loc. Cit.
}

Dalam hal sengketa bersenjata noninternasional, khususnya kerusuhan dan ketegangan internal ICRC memiliki hak inisiatif lainnya yang tidak ditetapkan dalam Konvensi tetapi dalam Statuta Gerakan, yang memungkinkannya untuk bertindak dalam keadaan perang singkat dan oleh karena itu tidak tercakup oleh hukum humaniter internasional. Hak inisiatif Statuta ini ditegaskan dalam pasal 5 ayat 3 Statuta dengan susunan kata-kata sebagai berikut: "Komite internasional dapat mengambil inisiatif kemanusiaan yang timbul dalam peranan sebagai lembaga yang secara khusus bersifat netral dan mandiri dan sebagai penengah, dan dapat mempertimbangkan persoalan apa pun yang memerlukan pemeriksaan oleh badan demikian".

Dalam hal ICRC memiliki hak inisiatif, tidak soal apa pun kondisinya Negara-negara dapat menolak pemberian bantuan yang dapat diperbaharui oleh ICRC. Jika Negara-negara yang terkena oleh sengketa menerima pemberian jasa tersebut, maka persetujuan yang dilahirkan merupakan dasar hukum bagi kegiatan-kegiatan ICRC.

Adapun satu contoh peran dari ICRC, yaitu saat terjadi pertempuran antara pasukan pemerintah dan milisi Taliban di Pakistan di Lembah Swat. Lembah itu telah menjadi lokasi operasi militer memberantas Taliban selama sebulan terakhir sehingga menyebabkan lebih dari dua juta orang terpaksa mengungsi.

Pada tanggal 31 Mei 3009, ketua delegasi komisi ICRC Pascal Cuttat di Pakistan mengumumkan bahwa warga Swat membutuhkan lebih banyak proteksi dan bantuan kemanusiaan, seperti dikutip di lama stasiun televisi CNN. Cuttat mengatakan ICRC akan melakukan semua hal dan mengerahkan bantuan tanpa ditunda lagi, ia pun berjanji ICRC akan menambah sumber daya mereka. Namun dia berharap pemerintah Pakistan dapat menjamin keselamatan dan kemudahan akses menuju wilayah Swat bagi pekerja ICRC. Selama ini ICRC telah mengevakuasi lebih dari 25 orang yang memerlukan perawatan medis.

Berdasarkan data Perserikatan Bangsabangsa (PBB), sekitar 2,4 juta warga Pakistan terpaksa mengungsi sejak 2 Mei lalu, dan pertempuran antara militer dan Taliban masih 
terjadi yang terpusat di kota terbesar di Swat, Mingora. ${ }^{21}$

Dalam hal ketegangan di wilayah satu Negara, seperti yang terjadi di Pakistan, ICRC pun turun tangan saat melihat banyak dampak negatif bagi para penduduk sipil, namun dalam hal ini ICRC juga berharap adanya jaminan keselamatan dan kemudahan untuk memasuki daerah pertempuran.

Praktik ICRC memberikan pelayanannya untuk perlindungan dan bantuan kepada orangorang yang terkena oleh kerusuhan atau ketegangan internal berurat-berakar dengan baik dalam tradisinya. Ini ditegaskan dalam resolusi ${ }^{22}$ Konferensi-konferensi Internasional Gerakan Palang Merah dan Bulan Sabit Merah dan Statuta baik Gerakan Palang dan Bulan Sabit Merah maupun ICRC sendiri. Negaranegara tidak pernah mempersoalkan prinsip actual yang melandasi praktik ini: dasar bagi tindakan ICRC dalam peristiwa kerusuhan dan ketegangan internal dengan demikian mendapatkan sifat kebiasaan (customary nature) dan pemberian jasa Komite Internasional dalam keadaan tersebut tidak merupakan campur tangan dalam urusan dalam negeri suatu Negara. Namun tidak ada kewajiban yang selaras pada pihak pemerintah untuk menerima tawaran demikian dalam keadaan tersebut yang menurut definisi, tidak tercakup oleh Konvensi-konvensi Jenewa.

Berbagai pelanggaran peraturan-peraturan kemanusiaan yang esensial yang terjadi dalam kerusuhan dan ketegangan internal sepenuhnya membenarkan pertimbangan kemanusiaan ICRC untuk melakukan tindakan dalam keadaan tersebut: kekerasan serampangan, tindakan terorisme, penyanderaan, peraturan-peraturan hukum yang dilanggar oleh perorangan atau oleh Negara, penghilangan secara paksa, buruknya kondisi penahanan, penyiksaan dan sebagainya.

Lingkaran kekerasan klasik dan penindasan acap mengarah kepada keadaan yang didalamnya orang-perorangan menurut faktanya - jika menurut hukum - kehilangan perlindungan Negara, baik karena pemerintah tidak lagi mampu memelihara ketertiban, atau

21 Lihat http://dunia.vivanews.com/nelvs/read/62532palang merah internasional khawatirkan warga

22 Resolusi (Resolution) adalah keputusan bersama untuk diajukan. Lihat Terminologi Hukum. karena dalam pemeliharaan ketertiban tersebut pemerintah juga melanggar prinsip-prinsip kemanusiaan.

Tugas tradisional ICRC dalam kasus-kasus kerusuhan dan ketegangan internal adalah mengunjungi tempat-tempat penahanan untuk memperbaiki keadaan penahanan.

Pada dasarnya semua keadaan kerusuhan dan ketegangan internal, kategori-kategori orang adalah dipenjarakan oleh para penguasa. Semua orang perorangan ini memiliki satu hal yang sama, yaitu: apa yang telah mereka lakukan, katakan atau tulis dipandang oleh para penguasa merupakan perlawanan serius terhadap system politik yang ada yang harus dihukum dengan mencabut kebebasan mereka. Tujuan hukum dari penahanan demikian bersifat penghukuman atau pencegahan, dengan tujuan pendidikan kembali atau pengintregasian kembali. Hukuman dapat diumumkan berdasarkan hukum yang lazim berlaku atau berdasarkan peraturan perundang-undangan darurat atau yurisdiksi ${ }^{23}$; kemungkinannya, hukuman itu mungkin timbul dari tindakan administratif yang berlaku selama periode yang terbatas atau tak terbatas. Kadang-kadang penangkapan mungkin merupakan tindakan umum dan serampangan yang mempengaruhi kelompok-kelompok besar orang.

ICRC dalam kaitannya dengan pemeliharaan kepercayaan semua pihak melalui kenetralannya, tidak terlibat dalam masalah politik pada akar kerusuhan dan ketegangan juga tidak mengomentari maksud dari penahanan tersebut; secara esensial ia sendiri: peduli dengan kondisi-kondisi material dan psikologis para tahanan.

2. Perlindungan Dalam Perang

Sebagaimana telah diketahui, penyiksaan dilarang dalam segala keadaan oleh hukum internasional dan hukum nasional sekaligus. Namun, di antara banyak masalah yang terkait dengan perlakuan 'tahanan politik' ICRC menganggap bahwa masalah penyiksaan mereka patut memperoleh perhatian khusus baik karena beratnya maupun karena acapnya hal tersebut terjadi, dan menghadapinya dengan tegas. Bagi ICRC perlindungan berarti

23 Yurisdiksi (Jurisdiction) ialah Kekuasaan untuk mengadili. Wilayah kekuasaan hukum. Lihat Terminologi Hukum. 
tidak hanya menjamin integritas fisik individual, tetapi juga integritas psikologisnya. Selama wawancara secara pribadi dengan para tahanan, para utusan ICRC mengisi banyak sekali formulir mengenai penganiayaan yang dipraktikkan kepada mereka. Tambahan atas berbagai penyiksaan fisik, para utusan mencatat seluruh rangkaian metode untuk menimbulkan penderitaan moral dan mental serta tekanan psikis yang merusak identitas personal para tahanan. Juga kondisi-kondisi material penahanan kadang-kadang sangat kurang, sehingga jika kondisi-kondisi itu merupakan kesengajaan, maka semuanya itu juga dapat dianggap sebagai penyiksaan. Fase interogasi ${ }^{24}$, masa-masa kurungan dan ketidakpastian yang disebabkan oleh penahanan tanpa dasar hukum secara jelas diperhitungkan di antara kepedulian para utusan ICRC.

\section{B. Hubungan Hukum Humaniter Internasional (HHI) dan Hak Asasi Manusia (HAM) Dalam Perlindungan Korban Sengketa Bersenjata}

Hukum humaniter internasional dan hak asasi manusia internasional saling melengkapi. Keduanya berusaha untuk melindungi kehidupan, kesehatan, dan martabat individu walaupun dari sudut yang berbeda.

Hukum humaniter berlaku dalam situasi konflik bersenjata, sedangkan hukum HAM, atau setidaknya sebagian darinya, melindungi individu pada setiap saat, baik di masa perang maupun di masa damai. Namun, beberapa perjanjian HAM memperbolehkan pemerintah untuk mengabaikan hak-hak tertentu dalam situasi darurat umum sedangkan pengabaian hak semacam itu sama sekali tidak diperbolehkan oleh $\mathrm{HHI}$ karena $\mathrm{HHI}$ disusun untuk situasi-situasi darurat yang disebut sebagai konflik bersenjata.

$\mathrm{HHI}$ ditujukan untuk melindungi orang-orang yang tidak, atau tidak lagi, terlibat dalam peperangan. Aturan-aturan yang terkandung dalam HHI membebankan kewajiban-kewajiban tertentu kepada semua pihak yang terlibat konflik. Hukum HAM, yang dirancang terutama untuk masa damai, berlaku bagi setiap orang. tujuan utamanya ialah untuk melindungi individu dari perilaku yang semena-mena oleh

\footnotetext{
24 Interrogation ialah pemeriksaan awal dalam perkara
} pidana. (Interogasi) Lihat Terminologi Hukum. pemerintahnya sendiri. Hukum HAM tidak berhubungan dengan perilaku peperangan.

Kewajiban untuk melaksanakan $\mathrm{HHI}$ dan Hukum HAM terletak pertama-tama dan terutama di tangan negara. HHI mewajibkan negara untuk mengambil langkah-langkah praktis dan langkah-langkah hukum seperti memberlakukan peraturan perundangundangan pidana dan menyebarluaskan $\mathrm{HHI}$. Demikian pula, negara terikat oleh hukum HAM untuk menyelaraskan hukum nasional dengan kewajiban-kewajiban internasional. $\mathrm{HHI}$ menetapkan sejumlah mekanisme tertentu yang membantu pelaksanaan hukum tersebut. $^{25}$ Perlu dicatat bahwa Negara diharuskan untuk memastikan agar $\mathrm{HHI}$ juga dihormati oleh negara lain.

Konsep hak-hak asasi manusia mempunyai dua pengertian dasar. Yang pertama ialah bahwa hak-hak yang tidak dapat dipisahkan dan dicabut adalah hak manusia karena ia seorang manusia. Hak-hak ini adalah hak-hak moral yang berasal dari kemanusiaan setiap insan dan hak-hak itu bertujuan untuk menjamin martabat setiap manusia. Arti yang kedua dari hak-hak asasi manusia adalah Hak-hak menurut hukum, yang dibuat sesuai dengan proses pembentukan hukum dari masyarakat itu sendiri, baik secara nasional maupun internasional. Dasar dari hak-hak ini adalah persetujuan dari yang diperintah, yaitu persetujuan dari para warga, yang merupakan dasar dari arti yang pertama tadi. ${ }^{26}$

Sesuai dengan sistem hukum hak asasi yang dianut ditingkat internasional, Negara ditempatkan sebagai aktor utama (Duty Holders). Sementara individu atau rakyat dalam suatu kelompok/masyarakat berkedudukan sebagai pemegang hak (Right Holders). Dengan demikian, Negara sesuai system HAM tersebut, sebenarnya tidak punya hak dan kepadanya hanya dipukulkan kewajiban dan tanggung jawab (Obligation atau Responsibility), tidak memiliki hak-hak yang dimiliki individu atau kelompok yang dijamin dalam instrument tersebut. Jika Negara tidak mau atau tidak punya keinginan untuk memenuhi kewajiban

\footnotetext{
25 Hukum Humaniter Internasional, Menjawab Pertanyaan Anda. ICRC Delegasi Indonesia, Versi Bahasa Indonesia, Februari 2008, hlm. 36-37

26 Levin Leah, Hak-Hak Asasi Manusia Tanya jawab, Jakarta: Pradnya Paramita, 1987, hlm. 3.
} 
itu, maka disinilah Negara dikatakan telah melakukan pelanggaran HAM. Dan jika pelanggaran tersebut tidak mau dipertanggungjawabkan oleh Negara, maka tanggung jawab itu diambil alih oleh masyarakat internasional. ${ }^{27}$

Melihat dunia, sejak tahun 1939 telah berkobar suatu peperangan yang sangat dahsyat, yang melibatkan sebagian besar masyarakat internasional, dengan NegaraNegara Poros di satu pihak dan Sekutu di pihak lain. Dengan berlalunya tahun-tahun, timbullah suatu kesadaran bahwa peperangan itu pada hakikatnya telah menjadi suatu pertikaian yang radikal antara Negara-negara.

Harus ada kesadaran akan pentingnya saling ketergantungan antara perdamaian dan hakhak asasi manusia, dan setelah perang itu harus dilakukan suatu usaha yang diperlukan untuk menjamin agar tercapainya tujuan ganda yang menjadi prioritas utama bagi semua Negara dan bagi masyarakat internasional secara keseluruhan, sebagaimana telah dikemukakan oleh Winston Chruchill tahun 1946 "untuk member ikan rasa aman kepada rumah yang tidak terhitung jumlahnya ini, ia harus dilindungi dari dua perompak raksasa, perang dan tirani. ${ }^{28}$

Dari deklarasi sedunia tentang Hak-Hak Asasi Manusia 10 Desember tahun 1948, telah disepakati oleh Negara-negara anggota penandatanganan deklarasi bahwa adanya pengakuan atas martabat alamiah dan hak-hak yang sama dan tidak terasingkan dari semua anggota keluarga kemanusiaan adalah dasar dari kebebasan, keadilan dan perdamaian di dunia.

Sesungguhnya manusia sebagai makhluk ciptaan Tuhan Yang Maha Esa mempunyai kewajiban dan memelihara alam semesta dengan penuh ketaqwaan dan penuh tanggung jawab untuk kesejahteraan umat manusia, manusia oleh penciptanya dianugrahi hak asasi untuk menjamin keberadaan harkat dan martabat kemuliaan dirinya serta keharmonisan lingkungannya.

27 Liba H. Mastra. Pikiran, Pandangan, dan Pantauan mengenai HAM Menuju GOOD GOVERNANCE. Jakarta: Forum Komunikasi dan Praktisi Hukum Indonesia, 2002, hlm. 5.

28 Cassesse Anotonio, Hak Asasi Manusia di Dunia yang Berubah, Jakarta: Yayasan Obor Indonesia, 1994. hlm. 33.

\section{PENUTUP}

\section{A. Kesimpulan}

1. Peran ICRC untuk melindungi para korban perang, diklasifikasikan pada dua kondisi, yaitu Sengketa Bersenjata Internasional (Perang Antar Negara) dan Sengketa Bersenjata Non-Internasional (Perang Dalam Negeri). Adapun peranan International Committee of the Red Cross termuat juga dalam pasal 5 Statuta Gerakan Palang Merah dan Bulan Sabit Merah;

2. Hukum Humaniter dan Hukum HAM memang merupakan dua hal yang memiliki perbedaan cukup jelas, namun Hukum Humaniter dan Hukum HAM saling melengkapi. Dimana keduanya berusaha untuk melindungi kehidupan, kesehatan dan martabat individu walaupun dilaksanakan dalam situasi dan cara yang berbeda. Hukum Humaniter berlaku pada situasi konflik bersenjata, sedangkan Hukum HAM melindungi individu setiap saat, baik pada masa perang maupun dalam masa damai. Hukum Humaniter ditujukan untuk melindungi orang-orang yang atau tidak lagi terlibat dalam permusuhan, sedangkan Hukum HAM berlaku untuk siapa saja.

\section{B. Saran}

1. Terhadap para anggota International Committee of the Red Cross yang akan melakukan tugas kemanusiaan, baik itu sengketa bersenjata internasional maupun non-internasional agar diberikan akses dan fasilitas demi memungkinkan fungsi kemanusiaan, bahkan jaminan keselamatan berdasarkan persetujuan kedua pihak.

2. Bahwa peran International Committee of the Red Cross tidak terlepas diwaktu perang saja tapi juga pasca perang, yaitu agar Negara bisa memberikan kebebasan kepada International Committee of the Red Cross untuk memulihkan keadaan pasca perang antara lain mengunjungi dan mewawancarai para korban perang, dan mencari informasi untuk memulihkan hubungan keluarga. 
3. Kedepan agar setiap Negara meratifikasi Konvensi Jenewa dan Konvensi-konvensi lain yang berhubungan dengan peperangan, untuk mengatasi banyaknya para korban di medan peperangan, agar ketika hal yang tidak diinginkan terjadi yaitu perang, dapat tercipta perang yang manusiawi.

\section{DAFTAR PUSTAKA}

Ambarwati, Denny Ramhdany, Rina Rusman. Hukum Humaniter Internasional dalam Studi Hubungan Internasional. Jakarta: Rawawali Pers, 2009.

Baehr Peter, Pieter Van Dijk, Adnan Buyung Nasution, Leo Zwaak. Instrumen Internasional Pokok Hak-hak Asasi Manusia. Jakarta: Yayasan Obor Indonesia, 2001.

Cassesse Anotonio, Hak Asasi Manusia di Dunia Yang Berubah, Jakarta: Yayasan Obor Indonesia, 1994

Harroff Mario-Tavel, Kegiatan Komisi Internasional Palang Merah (ICRC) Pada Waktu Kekerasan Dalam Negeri, ICRC Delegation, Jakarta, 1993.

Leah Levin. Hak-hak Asasi Manusia Tanya Jawab. Jakarta: PT Pradnya Paramita, 1987.

Liba H. Mastra. Pikiran, Pandangan, dan Pantauan mengenai HAM Menuju GOOD GOVERNANCE. Jakarta: Forum Komunikasi dan Praktisi Hukum Indonesia, 2002.

Mu'in H. Umar, Gerakan Palang Merah dan Bulan Sabit Merah Internasional \& Perhimpunan Palang Merah Indonesia, Jakarta: Gramedia Pustaka Utama, 1999

Nickel James. HAK ASASI MANUSIA Making Sense of Human Rights, Refleksi Filosofis atas Deklarasi Universal Hak Asasi Manusia. Jakarta: Gramedia Pustaka Utama, 1996.

Parthiana I Wayan. Pengantar Hukum Internasional. Mandar Maju.

Permanasari Arlina, dkk. Pengantar Hukum Humaniter. Jakarta: Comite Internasional Geneva, 1999.

Robertson, G. QC. Kejahatan Terhadap Kemanusiaan, Perjuangan Untuk Mewujudkan Keadilan Global. Jakarta: Komnas HAM, 2002.
Rover, C. TO SERVE \& TO PROTECT Acuan Universal Penegakan HAM Internasional Committee of the Red Cross. Jakarta: RajaGrafmdo Persada, 1998.

Soegondo Lies. Kapita Selekta Hak Asasi Manusia "Perkembangan Pelaksanaan Hak Asasi Manusia di Indonesia. Jakarta: Pusdiklat Mahkamah Agung, 2002.

Ranuhandoko I.P.M. Terminologi Hukum, Indonesia-Inggris. Jakarta: Sinar Grafika, 1996.

\section{Peraturan Perundang-Undangan}

Konvensi Jenewa tahun 1949 tentang Perlindungan Korban Perang (Internasional Convention for the Protection of Victims of War)

Undang-Undang No. 39 Tahun 1999 Tentang Hak Asasi Manusia. Bandung: Citra Umbara,1999.

\section{Website}

http://www.eramuslim.com/berita/palestina/g aza kritis icrc desak dunia internasional tekan israel.htm

http:www.//id.wikipedia.org/wiki/perianjian.sa nfransisco

http://dunia.vivanews.com/news/read/62532palang merah internasional khawatirkan warga

http://www.voanews.com/indonesian/archive/ 2005-I 1/2005-11-04voal.cfhi?moddate $=2005-1$ 1-04 